\title{
NGOs and the International Law Commission Draft Articles on the Protection of Persons in the Event of Disasters: A Relationship of Mutual or Grudging Respect?
}

\section{Elena Evangelidis* \& Thérèse O’Donnell ${ }^{+}$}

\section{INTRODUCTION}

Disasters and the human suffering that follows is on the increase. ${ }^{1}$ Between 2005 and 2015, nearly 800,000 deaths were attributed to disasters. ${ }^{2}$ According to the UN, 134,000,000 people needed humanitarian assistance in 2018 alone. ${ }^{3}$ Certain states are identified as particularly prone to disasters but the catastrophic effects are often international. The paradigmatic case of transboundary harm is the 2004 Indian Ocean tsunami, which killed and affected people in twelve states. ${ }^{4}$ Even where disasters do not transcend territorial boundaries, domestic response capacities are often overwhelmed, necessitating international assistance. ${ }^{5}$ Although external states provide humanitarian relief, in practice, the majority of state aid is channelled through UN agencies and Non-Governmental Organisations (NGOs). ${ }^{6}$

Notwithstanding their catastrophic impact and the highly internationalised nature of meeting the resulting challenges, disasters have eluded international law's firm grasp. ${ }^{7}$ Indeed, the IFRC described disasters as a 'long neglected facet' and contrasted this with the extensive body of international humanitarian law, applicable in times of armed conflict. ${ }^{8}$ This has remained the case despite the UN General Assembly-sponsored International Decade for Natural Disaster Risk Reduction in the 1990s and the emergence of international disaster law (IDL) as a distinct

\footnotetext{
*LL.M. Candidate, University of Leiden, Netherlands.

${ }^{+}$Reader in Law, University of Strathclyde Law School, Scotland, UK

${ }^{1}$ This article makes no distinction between natural and human-made disasters. Greg Bankoff, 'No Such Things as “Natural Disasters": Why We Had to Invent Them', Harvard International Review(24 August 2010), K.Chmutina et al., 'Why natural disasters aren't all that natural' https://www.opendemocracy.net/ksenia-chmutina-jason-vonmeding-jc-gaillard-lee-bosher/why-natural-disasters-arent-all-that-natural accessed 23 May 2019

${ }^{2}$ IFRC, World Disasters Report 2016, Resilience - Saving Lives Today, 233-234, http://www.ifrc.org/Global/Documents/Secretariat/201610/WDR\%202016-FINAL_web.pdf accessed 23 May 2019

${ }^{3}$ UNOCHA Gobal Humanitarian Overview, IFRC World Disasters Report (2018) Leaving No One Behind https://media.ifrc.org/ifrc/world-disaster-report-2018/ accessed 23 May 2019.

${ }^{4}$ ILC, Protection of Persons in the Event of Disasters Memorandum by the Secretariat, UN Doc A/CN.4/590, p.12

${ }^{5}$ Ibid, p. 147.

${ }^{6}$ David Fisher, 'The Future of International Disaster Response Law', (2012) 55 German Yearbook of International Law, 87, 92. Similar trends pervade private funds.

${ }^{7}$ David P. Fidler, 'Disaster Relief and Governance after the Indian Ocean Tsunami - What Role for International Law?' (2005) 6 Melbourne Journal of International Law, 458, 459

${ }^{8}$ IFRC, World Disasters Report 2000, Focus on Public Health, 147-149 available at http://www.ifrc.org/Global/Publications/disasters/WDR/9000-WDR2000.pdf accessed 23 May 2019
} 
legal specialism. ${ }^{9}$ More specifically International Disaster Response Law (IDRL) forms part IDL's corpus, perhaps even occupying a distinct domain. ${ }^{10}$ Notwithstanding its profile, IDL/IDRL remained an unsystematised, patchwork of law. ${ }^{11}$ Its haphazard development ${ }^{12}$ may be explained by ad hoc, reactive approaches from various actors in a decentralised system, employing hard and soft law sources. ${ }^{13}$ The need for systematization was clear and in 2007 the ILC included the topic of the Protection of Persons in the Event of Disasters in its programme of work. ${ }^{14}$ A set of 18 draft Articles were adopted in $2016^{15}$ with recommendations for the elaboration of a treaty. ${ }^{16}$

Although two international agreements focus specifically on disaster relief, ${ }^{17}$ numerous multilateral agreements and bilateral agreements make significant contributions. ${ }^{18}$ A large number of memoranda of understanding and headquarters agreements (typically entered into between IGOs and NGOs and states) are also relevant. ${ }^{19}$ As noted, significant amounts of soft law, ${ }^{20}$ including resolutions of the U.N. General Assembly, ${ }^{21}$ U.N. Economic and Social Council, and the International Red Cross Red Crescent Movement (hereinafter the RCRC Movement) also feature. There are also political declarations; codes of conduct; operational guidelines; and internal U.N. rules and regulations. ${ }^{22}$ NGOs in particular have made distinctive contributions in the disaster field. As well as driving good practice and awareness of field realities, recent decades have seen greater prominence for their law-making efforts. ${ }^{23}$ Hugely

\footnotetext{
${ }^{9}$ UNGA Res 42/169 (11 December 1987) UNGA A/RES 42/169

${ }^{10}$ Fisher (n.6) 89-91

${ }^{11}$ Craig Allan \& Thérèse O’Donnell, ‘An Offer You Cannot Refuse? Natural Disasters, the Politics of Aid Refusal and Potential Legal Implications', 5 Amsterdam Law .Forum 36, 39 (2013).

${ }^{12}$ ILC 'Report of the International Law Commission on the Work of its Fifty-eighth Session', (1 May-9 June and 3 July-11 August 2006) UN Doc A/61/10, annex C para. 12-15.

${ }^{13}$ Arnold N. Pronto 'Understanding The Hard/Soft Distinction in International Law' (2015) 48 VNJTL 941

${ }^{14}$ Eduardo Valencia Ospina, , 'Preliminary Report on the Protection of Persons in the Event of Disasters' UN Doc A/CN.4/598 para.2

${ }^{15}$ ILC 'Report of the International Law Commission on the Work of its Sixty-eighth session' (2 May-10 June and 4 July-12 August 2016) UN Doc A71/10. All subsequent references to draft Articles, unless otherwise noted, refer to this instrument.

${ }^{16}$ Supported and reiterated by UNGA Res 71/141 '(13 December 2016) UN Doc A/RES/71/141 and UNGA Res 73/209 (20 December 2018) UN Doc A/RES73/209.

${ }^{17}$ Convention on Assistance in the Case of a Nuclear Accident or Radiological Emergency, 1998 Tampere Convention on the Provision of Telecommunication Resources for Disaster Mitigation and Relief Operations.

${ }^{18}$ Valencia Ospina, Prelim. Rep. (n.14) paras 33-35, 37.

${ }^{19} \mathrm{~A} / 61 / 10$ (n.12) para. 14

${ }^{20}$ Dug Cubie, 'An Analysis of Soft Law Applicable to Humanitarian Assistance: Relative Normativity in Action?', 2 JIHLS (2011) 177

${ }^{21}$ Notably UNGA Res 46/182 (19 December 1991) 'UN Doc A/RES/46/182.

${ }^{22} \mathrm{~A} / 61 / 10$ (n.12) paras.12-15.

${ }^{23}$ Michael Reisman, 'From the Law of Nations to Transnational Law: Why We Need a New Basic Course for the International Curriculum’ (2003-20040 22 Penn St. Int'l L. Rev. 397, 403-404
} 
influential IDL instruments (discussed in detail in section 3) have included the Sphere Handbook $^{24}$ and the Code of Conduct for the International Red Cross and Red Crescent Movement and Non-Governmental Organizations in Disaster Relief. ${ }^{25}$ Of even greater importance are the 2007 IFRC IDRL Guidelines for the Domestic Facilitation and Regulation of International Disaster Relief and Initial Recovery Assistance ${ }^{26}$ which were particularly influential on the ILC drafting project. As well as revealing the scale of the task facing the ILC in its codifying project, the foregoing analysis also highlights the ILC's task of addressing the peculiarly conspicuous role of NGOs in this field and the potential legal consequences of their prominence.

The draft Articles acknowledged NGOs' central contribution both in the field and in relevant rule-formation and indeed draft Article 3's commentary drew much from the Red Cross Code of Conduct. ${ }^{27}$ Arguably, therefore, the ILC's draft Articles recognise and fortify this important role of NGOs. As well as interfacing with NGOs in the consultation and drafting process (although, as noted subsequently, beyond the RCRC Movement, this was rather limited) the draft Articles clearly note NGOs' importance by often articulating their roles in the same provisions where recognition is given to the functions of states and the UN. Indeed, during the drafting processes some states were concerned that NGOs were being accorded recognition beyond what was acceptable or wise.

This article analyses the role of NGOs in the development and drafting of disaster law in general, and the ILC draft Articles in particular, and by extension what this reveals regarding NGO subjectivity in international law. The substantive content of the draft Articles and their commentaries and how they pertain to NGOs from an operational perspective, is a further area of analysis. The article initially frames humanitarian NGO subjectivity and how this constituency has evolved and how that has implications for its realm of action. Secondly, given its underpinning importance to the ILC project, an analysis of NGO disaster law activity (both autonomous and institutional) is analysed via key instruments. NGOs are a complex and diverse community and attempts to address them in some standardised fashion (which was also

\footnotetext{
${ }^{24}$ The Sphere Project, Humanitarian Charter and Minimum Standards in Disaster Response (revised in 2011) http://www.ifrc.org/PageFiles/95530/The-Sphere-Project-Handbook-20111.pdf accessed 23 May 2019.

${ }^{25} \mathrm{https} / / / w w w . i c r c . o r g / e n / d o c / a s s e t s / f i l e s / p u b l i c a t i o n s / i c r c-002-1067 . p d f$ accessed 23 May 2019.

26 https://www.ifrc.org/PageFiles/41203/1205600-IDRL\%20Guidelines-EN-LR\%20(2).pdf accessed 23 May 2019.

${ }^{27}$ Draft Article 3 Commentary, para. 6.
} 
acceptable to states) was always going to challenge the ILC. These complexities are analysed in the final main substantive section of the article with particular attention being given to draft Article 12 and the issue of external assistance to disaster-affected states.

\section{NGOS AS SUBJECTS OF INTERNATIONAL LAW}

Globalisation's advent, with its attendant phenomena of state interdependence and global IGO governance, has generated persistent questioning of statehood's pre-eminence. However, while globalisation might explain the causes and factual reality of NGO interventions, questions remain open regarding the extent of NGOs' legal personality. In terms of lawmaking, a related but distinct issue concerns the potential challenge NGOs represent to the positivist Westphalian orthodoxy $y^{28}$ (and its attendant shibboleth of inherent state sovereign will ${ }^{29}$ ) and core notions of legitimacy. ${ }^{30}$. While NGOs' direct impact on rule-formation can be denounced as illegitimate due to the absence of traditional authorising mandates, ${ }^{31}$ NGOs have nevertheless significantly developed IDL. This section discusses issues regarding NGO personality and provides context for the subsequent analysis of NGOs' development of IDL norms and standards.

NGOs are often more easily defined by what they are not. ${ }^{32}$ They are often counter-posed to international organisations composed of sovereign states, ${ }^{33}$ those established by governments or by intergovernmental agreement, ${ }^{34}$ and those funded publicly. ${ }^{35}$ There is no essential structural organisation to NGOs, with some operating solely in a single state and others operating internationally and transnationally. Despite presumptions as to their left-leaning bias, NGOs represent a considerable diversity of views and interest groups. ${ }^{36}$ Nevertheless, they are classically perceived as acting in the common interest. ${ }^{37}$

\footnotetext{
${ }^{28}$ Steve Charnovitz 'Nongovernmental Organizations and International Law', 100 (2006) American Journal of International Law 348, 360.

${ }^{29}$ Martti Koskenniemi, From Apology to Utopia (CUP 2005) 167.

${ }^{30}$ RüdigerWolfrum, International Law (MPEPIL 2006) 83.

${ }^{31}$ Ibid 88 .

${ }^{32}$ Alan Boyle \& Christine Chinkin, The Making of International Law (OUP 2007) 41.

${ }^{33}$ Dwight W. Morrow, The Society of Free States (Harper 1919), in Charnovitz (n.28)351.

${ }^{34}$ rather than by private initiative, ibid, 350 .

${ }^{35}$ Boyle \& Chinkin (n.32) 53.

${ }^{36}$ See the National Rifle Association, Boyle \& Chinkin (n.32), 210.

37 'Non-State Actors and their Influence on International Law' (1998) 92 ASIL Proceedings, 381, Remarks by Diane Otto.
} 
The mainstream definition of international law subjects is that such entities are capable of exercising rights, making claims and bearing duties in international law. ${ }^{38}$ Although there continue to be detractors, ${ }^{39}$ the hitherto dominant hyper-Westphalian, state-centric system has been displaced. 'New actors' which emerged in the late- $20^{\text {th }}$ century now claim the benefits of international legal personality. ${ }^{40}$ Nevertheless, as the ILC drafting debates evidence, controversies endure as to the extent (or limits) of NGO personality. On one reading, if participation is subjecthood's key defining quality ${ }^{41}$ then NGOs' personality seems undeniable. However, visibility and profile do not equal meaningful partnership. NGOs might draft key IDL instruments but, as Mexico articulated in the UNGA Sixth Committee deliberations on draft Article 12, if there was a right to offer assistance, only subjects of international law could exercise that right. ${ }^{42}$ The clear implication was that NGOs lacked genuine subjecthood. In his redrafting of draft Article 12 (which, as will be seen in section 4, removed any notions of rights and distinguished between categories of assisting actors) the ILC Special Rapporteur Eduardo Valencia Ospina tactfully acknowledged such concerns but delicately sidestepped the issue of the extent of NGO personality.

The draft Articles also seemingly draw an early bright-line by stressing that the ILC's primary focus is not NGO regulation. Draft Article 1's commentaries stress that the project centres on the activities of states, IGOs and other entities enjoying specific international legal competence in the disaster relief context. Activities of NGOs and other 'civil society' actors are included only in a secondary manner either as direct beneficiaries of state duties (such as the state duty to cooperate) or indirectly via domestic laws implementing the draft Articles. ${ }^{43}$ However, despite this attempt at delineation, explicit and implicit references to NGO influence throughout the draft Articles highlight the complicated relationship between states, NGOs and international law with which the ILC had to grapple. As will be seen in the next section, fluctuations in general humanitarian mandates, and variations in individual NGOs' social and political capital further complicated attempts to analyse and systematize their legal identity.

\footnotetext{
${ }^{38}$ James Crawford, Brownlie's Principles of Public International Law (OUP 2012) Chapter 4.

${ }^{39}$ Colin Warbrick 'States and Recognition in International Law' in Malcolm Evans (ed.), International Law (OUP 2006) 217.

${ }^{40}$ Reparation for Injuries (Advisory Opinion) 1949 [178] Robert McCorquodale, The Individual in International Law' in Malcolm Evans (ed.) International Law (OUP 2018) 259.

${ }^{41}$ Rosalyn Higgins, Problems and Process (OUP 1994) 49

${ }^{42}$ UN Doc A/C.6/66/SR.22, para.20.

${ }^{43}$ Draft Article 1 Commentary, para. 3.
} 


\subsection{Fluctuating Humanitarianism: Impartiality and Human Rights-Based Solidarity}

Until the early 1990s, the RCRC Movement's monopoly on defining and elaborating the standards applicable to humanitarian aid missions meant that the principles of humanity, impartiality, neutrality and universality dominated. ${ }^{44}$ Theoretically, these removed NGO activity from political context $\mathrm{t}^{45}$ and were considered to be particularly enabling during the Cold War. ${ }^{46}$ This ethos endures, ${ }^{47}$ as reflected in ILC draft Article 6, where the aforementioned principles still operate as central reference points.

Over time, however, the humanitarian movement broadened its field of activities, progressing from the provision of immediate relief, to strategies reflecting long-term solidarity and developmemt and advocacy on behalf of victims. Faced with difficult questions of strategic choice and prioritisation, NGOs defended their selection via the language of ethics and morals. ${ }^{48}$ However, this retreat entailed decisions about rightness and just causes, the deserving and undeserving, which made explicit the politicisation of the humanitarian endeavour. ${ }^{49}$ This re-routing of NGO objectives accompanied changes in their roles in the global order. The Biafran Famine of 1968 and the perceived failures of the humanitarian system relating to the 1994 Rwandan genocide are commonly cited as watershed moments ${ }^{50}$ and need no rehearsal here. However, it is worth noting that the twin principles of 'freedom of criticism' (permitting NGO denunciation of parties to a conflict) and 'subsidiarity of sovereignty', (also called the 'right to intervention') signalled turns from the dominant orthodoxy of needs-based humanitarianism. Inevitably, the application of such judgments raised anxieties as to how the common interest could be separated from self-interest'. ${ }^{51}$ Shaped by the eye of the beholder and culturally situated, there is no single vision of the 'common interest'. The concept's susceptibility to appropriation by elite interests ${ }^{52}$ inevitably sparked concerns about the the

\footnotetext{
${ }^{44}$ David G. Chandler, 'The Road to Military Humanitarianism - How the Human Rights NGOs Shaped a New Humanitarian Agenda' (2001) 23(2) Human Rights Quarterly, 678, 679, 682.

${ }^{45}$ Daniel Warner, 'The Politics of the Political/Humanitarian Divide', (1999) 81 International Review of the Red Cross 109.

${ }^{46}$ Chandler (n.44) 681.

${ }^{47}$ Amnesty International, 'Our Story - Defending our Human Rights for Over 50 Years'

https://www.amnesty.org.uk/about-amnesty-international-human-rights accessed 23 May 2019

${ }^{48}$ Chandler (n.44) 683.

${ }^{49}$ Nicholas Leader, 'Proliferating Principles - or How to Sup with the Devil without Getting Eaten (1998) 22

Disasters, 295.

${ }^{50}$ Alex De Waal, Famine Crimes 72-77 (Currey 1997). See Bernard Kouchner's statement, as quoted in Jonathan Benthall, Disasters, Relief and the Media, (Kingston 1993) 125. Rwanda in particular highlighted the softness of certain legal instruments.

${ }^{51}$ Otto (n.37) 381-382

${ }^{52}$ Martti Koskenniemi, 'International Law: Between Tradition and Renewal', (2005) 16 European Journal of International Law 113, 116
} 
assumed moral rectitude of NGOs which were operating in highly politicised environments. Humanitarianism gave no guarantees of NGOs' insulation from the same self-interest, political calculations and partial representation of which states were often accused, but about which NGOs were infinitely less transparent or accountable. This anxiety almost certainly underpinned the ILC debates as critique of NGOs built across the political and social spectrum. ${ }^{53}$ A further layer of complexity arises from the quite different standing of individual NGOs, which is now discussed.

\subsection{NGO Diversity - Insiders or Outsiders}

Although NGOs' profile has rocketed, they occupy very different places within the international order, ${ }^{54}$ depending on their position as 'insiders' or 'outsiders'. ${ }^{55}$ The contrasting cases of the RCRC Movement and small social change activists illustrate this divergence.

The RCRC Movement consists of three autonomous components with their own legal status: The International Federation of the Red Cross and Red Crescent Societies (IFRC), the International Committee of the Red Cross (ICRC), and the National Societies. ${ }^{56}$ As a collection of private associations formed under Swiss law, the RCRC Movement does not fit the criteria of an IGO, and so, the ICRC and IFRC are therefore most commonly referred to as $\mathrm{NGOs}^{57}$ despite this characterisation inadequately capturing their international legal status. For example, both the ICRC and the IFRC have bilateral status agreements with almost 60 countries, granting them certain privileges and immunities which parallel those enjoyed by IGOs ${ }^{58}$ Although the case of the IFRC/ICRC is unique, they represent paradigmatic 'insiders'.

\footnotetext{
${ }^{53}$ Kim D. Reimann, 'Up to No Good? Recent Critics and Critiques of NGOs', in Henry F. Carey, Subcontracting Peace: The Challenges of NGO Peacebuilding (Routledge 2005)

James McGann and Mary Johnstone 'The Power Shift and the NGO Credibility Crisis' https://www.globalpolicy.org/component/content/article/176/31423.html, accessed 23 May 2019.

Nidhi Srinivas, 'Against NGOs: A Critical Perspective on Nongovernmental Action' (2009) 38(4) Nonprofit and Voluntary Sector Quarterly 614

${ }^{54}$ Christian Walter, Subjects of International Law (MPEPIL 2007) 21, McCorquodale, (n.84).

${ }^{55}$ Otto (n.37) 382.

56 http://www.ifrc.org/en/who-we-are/the-movement/ accessed 23 May 2019

57 See for example, Chandler (n.44), Boyle \& Chinkin (n.32) 42

${ }^{58}$ Els Debuf, 'Tools to Do the Job: The ICRC's Legal Status, Privileges and Immunities' International Review of the Red Cross' 97 (2016) 319; Elise Baudot Quéguiner, 'The Laws and Principles Governing Preparedness Relief and Rehabilitation Operations: the unique case of the International Federation of Red Cross and Red Crescent Societies' in International Disaster Response Laws, Principles and Practice - Reflections, Prospects and Challenges, (IFRC 2003)
} 
In terms of broad, institutional participation, the 'Arria-formula' enables NGO representatives to informally meet with UN Security Council. ${ }^{59}$ Similarly, Article 71 of the UN Charter, provides for ECOSOC consultation with NGOs. ${ }^{60}$ This allows NGOs with consultative status to attend various types of UN meetings as observers, including law-making diplomatic conferences. ${ }^{61}$ The legal recognition afforded by the UN Charter affords NGOs a unique standing among civil society actors, and indicates the indispensable value of NGO-status regarding access to the UN system. ${ }^{62}$ Resolution 1996/31 ${ }^{63}$ embodies the "NGO statute" ${ }^{64}$ and establishes criteria for obtaining consultative status. ${ }^{65}$ Initially, such criteria apparently promoted wider participation beyond major international NGOs to grassroots and Global South NGOs. ${ }^{66}$ However, closer examination reveals that non-mainstream and developing countries' NGOs remain disadvantaged in gaining accreditation. ${ }^{67}$ For example, NGOs need a sophisticated and professional organisational structure ${ }^{68}$ which may challenge bodies with small memberships or limited funds. Three different categories of status can be accorded. NGOs with general consultative status (the most extensive) may, for example, submit written statements of up to 2000 words, request that items be placed on the ECOSOC's agenda, and designate representatives to sit as observers at public meetings of the commissions and other subsidiary organs of ECOSOC. To acquire such status, however, NGOs must inter alia be 'broadly representative of major segments of society in a large number of countries in different regions of the word', which hardly guarantees equality of access. Mertus analyses the inevitable divisions in her taxonomy of civil society, in which she distinguishes 'kitchen tablers' (local social change activists) from global NGOs which can access international fora or indeed organise their own international events. ${ }^{69}$ This demarcation within civil society reveals 'outsiders' lacking the access which 'insiders' enjoy to the spaces where international norms are actually developed. Further, when 'outsiders' do find the opportunity to speak, they

\footnotetext{
${ }^{59}$ UN Security Council Working Method, 'Arria-Formula Meetings' http://www.securitycouncilreport.org/unsecurity-council-working-methods/arria-formula-meetings.php accessed 23 May 2019

60 UN Charter Art. 70.

${ }^{61}$ Boyle \& Chinkin (n.32) 54

${ }^{62} \mathrm{Ibid}, 45$.

${ }^{63}$ This replaced Resolution 1296 and implemented ECOSOC's mandate.

${ }^{64}$ Barbara K.Woodward, 'The Role of International NGOs-An Introduction', (2011) 19 Willamette Journal of International Law \& Dispute Resolution 203, 207

65 'Consultative Relationship Between the United Nations and Non-Governmental Organizations' UN Doc. E/RES/1996/31 paras.1-17, 22-30

66 Ibid, paras.4-6

${ }^{67}$ Julie Mertus, 'Considering Nonstate Actors in the New Millennium - Toward Expanded Participation in Norm Generation and Norm Application', 32 (2000) New York .University Journal of International Law \& Policy, 537, 562

${ }^{68}$ E/RES 1996/31 (n.116) $₫ 10-12$

${ }^{69}$ Mertus (n.67) 542
} 
are arguably not heard in meaningful ways. ${ }^{70}$ This is illustrated in the later discussion in section 3 regarding the Inter-Agency Standing Committee.

In the ILC Consultation process on the draft Articles, it was notable that of the non-state, nonIGO bodies which participated, none were grassroots organisations. Indeed, only the RCRC Movement, the ultimate insiders, received invitations to comment and understandably took full advantage of this opportunity. Despite the draft Articles' textual attempts to more explicitly recognise the NGO role, their drafting process actually perpetuated shortcomings in NGO participation in institutional law-making (further examined in section 3).

\section{THE ROLE OF NGOS IN INTERNATIONAL DISASTER LAW}

Diverse NGO roles reflect the heterogeneity of the actors themselves,${ }^{71}$ with activities being broadly divided into the law-making, administration, and enforcement. ${ }^{72}$ Law-making is this article's focus and so analysis will be divided into two main sections: one concerning autonomous NGO activity and another focussing on NGO activity within the institutional sphere, with case studies of both. Given its inherently state-centric nature, ${ }^{73}$ NGO participation in law creation is potentially transformative in terms of the process. ${ }^{74}$ Although Article 38 of the International Court of Justice's Statute makes no specific mention of NGOs, ${ }^{75}$ in reality, they are involved in all contemporary international law-making mechanisms.

International law can be analysed along two axes; process and enforceability. Process involves institutionalised and non-institutionalised processes with the result being categorised as 'hard' or 'soft' law. ${ }^{76}$ A legal instrument's enforceability derives from its developmental process since traditionally state consent is necessary to produce a binding, hard instrument. Soft law includes non-binding instruments, such as international declarations, recommendations or resolutions concluded by IGOs and other non-State actors. ${ }^{77}$ While not binding per se, soft law can transform its nature through later treaty inclusion or via the crystallisation of customary

\footnotetext{
${ }^{70}$ Ibid 546.

${ }^{71}$ ASIL Proceedings (n.37) Remarks by Christine Chinkin, 380.

72 Woodward (n.108) 212.

73 Jan Klabbers, International Law (CUP 2018) 24-25.

${ }^{74}$ ASIL Proceedings (n.37) Chinkin, 380.

${ }^{75}$ See Article $38(1)(d)$ - subsidiary source of the 'teachings of the most highly qualified publicists'.

${ }^{76}$ Woodward (n.108) 21, Dinah Shelton "International Law and 'Relative Normativity"” in Malcolm Evans (ed.) International Law (ed.) (OUP 2014) 137.

${ }^{77}$ Ibid. Alan Boyle 'Soft Law International Law-Making' in Evans (n.40) 119.
} 
law (involving generations of state practice usage and intonations). ${ }^{78}$ NGOs in particular demonstrate their autonomous law-making ability by drafting guidelines, codes of conduct, expert papers and research. As soft law, such instruments depend for their authority on the prestige of both authors and organisations concerned. ${ }^{79}$ Epistemic communities, such as the International Law Association, command a high degree of authority via the standing of their members. ${ }^{80}$ One noteworthy example is the 2003 Institut de Droit International's (IDI) Bruges resolution on humanitarian assistance. ${ }^{81}$ A hugely significant IDL document in itself, it also impacted the ILC draft Articles considerably. The Special Rapporteur makes reference to the resolution several times, most importantly in relation to draft Article 11 regarding an affected state's duty to seek assistance, the formulation of which derives specifically from Article III, paragraph 3 of the Bruges resolution. ${ }^{82}$ More generally, where there is a legal vacuum, instruments like the Bruges resolution are cited to demonstrate that the way has been paved for binding rules. ${ }^{83}$ NGOs also demonstrate considerable energy and skills in drafting texts which form blueprints for later instruments including treaties. ${ }^{84}$ Indeed, the 2007 IFRC IDRL Guidelines mentioned in the introduction, though soft, enjoy exceptional standing in legal and humanitarian circles through their expert drafting by a key humanitarian NGO (the IFRC). They undoubtedly signposted, and were an acknowledged influence upon, the draft Articles as discussed in very shortly.

As independent actors, NGOs can develop influential relations with major institutions. They are often key in the treaty-making process by identifying and promoting areas of legal reform. ${ }^{85}$ At international conferences they are peerlessly prepared and effective lobbyists. NGOs also influence informal institutional law-making processes, notably via UN General Assembly resolutions which are often extremely impactful. Of particular note are the Guiding Principles on Humanitarian Assistance which were annexed to UN General Assembly Resolution 46/182

\footnotetext{
${ }^{78}$ North Sea Continental Shelf Cases (FRG v Denmark, FRG v Netherlands) [1969] I.C.J. Rep. 3, 43.

${ }^{79}$ Boyle \& Chinkin (n.32) 89. See Richard B. Lillich, 'Current Developments - The Paris Minimum Standards of Human Rights Norms in a State of Emergency’ (1985) 79 American Journal of International Law 1072.

${ }^{80}$ Ibid, Boyle \& Chinkin (n.32) 89.

${ }^{81}$ Institute of International Law, Resolution on Humanitarian Assistance (2 September 2003) Bruges.

${ }^{82}$ Art. 11 Commentary para.5.

${ }^{83}$ See, for example, Thérèse O’Donnell and Craig Allan, 'A Duty of Solidarity’, in Susan C. Breau \& Katja L.H. Samuel(eds.) Research Handbook on Disasters and International Law (Elgar 2016) 453, 462 regarding duties to offer disaster assistance.

${ }^{84}$ Boyle \&Chinkin (n.32) 64

${ }^{85}$ For examples see ICRC and the Protocol IV on Blinding Laser Weapons, ibid 63.
} 
(1991), and which were described as 'foundational' 86 and 'landmark arrangements for putting in place a coordinated and effective system for humanitarian emergency assistance'. ${ }^{87}$

The next section focuses on case studies analysing NGOs' independent and institutional contributions to IDL creation. The former technique is best illustrated in the IFRC's Disaster Law Programme (DLP). Although states were involved, NGOs (particularly the IFRC) drove and developed the DLP. The aforementioned Sphere Handbook and the 1994 Red Cross Code of Conduct are also examined. The World Inter-Agency Standing Committee and the Conferences on Disaster Risk Reduction illustrate the (perhaps more precarious) role of NGOs in institutional initiatives. The ILC Draft Articles as a product of a UN agency also highlight this facet of the NGO law-making role, but given their thematic centrality to this article, this influence is focused upon in detail in section 4.

\subsection{Autonomous NGO activity in International Disaster Law}

\section{(i)IFRC International Disaster Law Programme and the 2007 IDRL Guidelines}

Bookmiller captures the IFRC's integral contribution to disaster law by stating that ' $[\mathrm{t}] \mathrm{he}$ Federation has taken what was an essentially non-existent strand of law two decades ago and [has] moved it to the centre of a genuine disaster management discourse' ${ }^{88}$ In 2001 a resolution of the RCRC Council of Delegates created the IFRC Disaster Law Programme. ${ }^{89}$ Its objectives included advocating for the disaster law's development and improvement through the compilation and publication of existing laws and regulations and the evaluation of their effectiveness in practice. It also sought partnership with national governments to promote appropriate laws and regulations. ${ }^{90}$ The project initially found that despite a plethora of instruments, the existing patchwork of rules and systems suffered from significant gaps and overlaps. $^{91}$ Domestic authorities also lacked familiarity with relevant instruments and how they empowered governments to address some post-disaster challenges. Consequently, the

\footnotetext{
86 Sandesh Sivakumaran, 'Techniques in International Law-Making: Extrapolation, Analogy, Form and the Emergence of an International Law of Disaster Relief, (2017) 28(4) European Journal of International Law 1097, 1102.

${ }^{87}$ Ibid 1102

${ }^{88}$ Kirsten N. Bookmiller, 'Closing “the yawning gap”? International Disaster Response Law at Fifteen', in Breau, \& Samuel (n.83) 46, 59

${ }^{89}$ Initially entitled 'The Disaster Response Law Programme', 'response' was removed in 2012 to reflect the project's

evolution http://www.ifrc.org/PageFiles/139513/name\%20change\%20announcement_FINAL\%20LATEST\%2002.02.201 2.pdf accessed 23 May 2019

${ }^{90} \mathrm{http}$ ///www.ifrc.org/PageFiles/139513/idrl-cod-2001s.pdf accessed 23 May 2019

${ }^{91}$ IFRC, International Disaster Response Laws (IDRL) Project Report 2002-2003 14-17
} 
IFRC re-focussed to promote IDRL in particular ${ }^{92}$ and responded to the International Conference of the RCRC Movement's call for it to develop 'guidelines for ... practical use in international disaster response activities'. ${ }^{93}$ In 2006 and 2007, the IFRC organised a series of regional conferences, where over 140 governments, 140 National RCRC Societies, and a number of international organisations and NGOs participated in order to provide drafting input into the Guidelines for the Domestic Facilitation and Regulation of International Disaster Relief and Initial Recovery Assistance.

The final IDRL Guidelines were adopted by states and RCRC actors at the $30^{\text {th }}$ International RCRC Conference, and were quickly recognised ${ }^{94}$ as a landmark in disaster law. Numerous domestic laws and rules have drawn language or inspiration from the IDRL Guidelines, with an acknowledged influence upon the laws and practices of 22 states including majorly prone disaster territories. ${ }^{95}$ More than twenty states confirmed their active use of the Guidelines and their involvement of relevant stakeholders in dialogue regarding them. ${ }^{96}$ The Guidelines have influenced $21 \mathrm{UNGA}$ resolutions ${ }^{97}$ and numerous resolutions of other $\mathrm{IGOs}^{98}$ and regional organisations. ${ }^{99}$ As well as driving development of the IDRL Guidelines, the IFRC engaged in follow-up cooperation with states to ensure their acceptance and increased legitimacy. Strikingly, this process reveals a reversal of the traditional roles played by states and NGOs in international conference law-making. In this example, the IFRC provided a space for the development of international law, while states' presence bestowed the guidelines with legitimacy. Given their chronological proximity and thematic sympathies, the complementary

\footnotetext{
92 Bookmiller (n.88) 57-59.

93 http://www.ifrc.org/PageFiles/41203/1205600-IDRL\%20Guidelines-EN-LR\%20(2).pdf 'Introduction', 7 accessed 23 May 2019.

${ }^{94}$ By 2011, seven states had incorporated the guidelines or some aspects of them into domestic law with 22 states initiating regulatory reviews in light of them $31^{\text {st }}$ International Conference of the Red Cross and Red Crescent, $\begin{array}{llllll}\text { Geneva } & (28 & \text { November } & - & 1 & \text { December }\end{array}$ http://www.ifrc.org/PageFiles/41203/IDRL\%20progress\%20report.pdf, 5 accessed 23 May 2019

95 https://www.ifrc.org/what-we-do/disaster-law/about-disaster-law/international-disaster-response-laws-rulesand-principles/idrl-guidelines/new-legislation-adopted-on-idrl/ (accessed 23 May 2019). 96 Ibid 6.

97 https://www.ifrc.org/en/what-we-do/idrl/research-tools-and-publications/key-resolutions/un-generalassembly-resolutions-on-the-idrl-guidelines/ (accessed 23 May 2019). See most recently UN GA Res 72/133 (11 December 2017) UN Doc A/RES/72/133.

${ }^{98}$ UN ECOSOC Resolution 2014/13 of 14 August 2014 on Strengthening of the coordination of emergency humanitarian assistance of the United Nations.

Resolution of the Customs Co-operation Council on the Role of Customs in Natural Disaster Relief, of June 2011. ${ }^{99}$ Organisation of American States (OAS) Resolution 2750 of 4 June 2012 on Existing Mechanisms for Disaster Prevention and Response and Humanitarian Assistance Among the Member States, and the InterAmerican Plan of 9 May 2012.

Forty-third Pacific Islands Forum, Forum Communiqué, of 28-20 August 2012. European Union, European Consensus on Humanitarian Aid, January 2008.
} 
relationship between the IDRL Guidelines and the Draft Articles reveals mutually reinforcing and supportive outcomes, and healthy state/NGO partnerships.

\section{(ii)In pursuit of Good Practice: The Sphere Handbook}

The Sphere Project ('Sphere') was initiated in 1997 by a group of NGOs and the RCRC Movement to improve the quality of humanitarian response for conflict and disaster-affected populations. The Handbook consists of interlinked parts including the Humanitarian Charter, Protection Principles, Core Standards and Minimum Standards. The Charter targets humanitarian-response practitioners and provides the ethical and legal context underpinning the minimum standards. States, their related entities, and the private sector are secondary addressees. Sphere identifies as a 'community of humanitarian response practitioners' governed by representatives of global networks of humanitarian agencies. ${ }^{100}$ It has no membership or accreditation process and the Handbook is entirely voluntary. ${ }^{101}$ Furthermore, the project exists entirely outside of the official law-making framework of states or IGOs. Consequently, in the absence of signatories, a compliance mechanism or state consent, the Sphere Handbook is clearly soft law. ${ }^{102}$ Nevertheless, its standards mimic the guidance found in treaties, legislation and regulations. As the most comprehensive set of quality standards for disaster response, ${ }^{103}$ the Handbook is a central reference and, despite criticism, the Sphere standards enjoy wide acceptance. ${ }^{104}$ Indeed the Special Rapporteur cited them with approval several times. ${ }^{105}$ While translating the standards into customary international law would certainly be a long process involving adoption by states via state practice and opinio juris, Sphere's terms could ultimately acquire binding force upon states. ${ }^{106}$

\footnotetext{
100 http://www.sphereproject.org/about/ accessed 23 May 2019

${ }^{101}$ Ibid

${ }^{102}$ IFRC, World Disaster Report 2000 (n.8) 153.

${ }^{103}$ Secretariat Memorandum (n.4) para. 196.

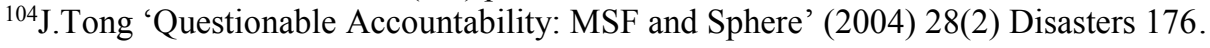

Koenraad Van Brabant 'Regaining Perspective: The Debate over Quality Assurance and Accountability' https://odihpn.org/magazine/regaining-perspective-the-debate-over-quality-assurance-and-accountability/ accessed 23 May 2019.

Severine Frison, JamesSmith, Karl Blanchet, 'Does the Humanitarian Sector Use Evidence-informed Standards? A Review of the 2011 Sphere Indicators for Wash, Food Security and Nutrition, and Health Action', (2018) http://currents.plos.org/disasters/index.html\%3Fp=38647.html accessed 23 May 2019.

See in particular Tommasso Natoli 'Non-state humanitarian actors and human rights in disaster scenarios: normative role, standard setting and accountability', in Flavia Zorzi Giustiniani, Emanuele Sommario, Federico Casolari, Giulio Bartolini (eds.)

Routledge Handbook of Human Rights and Disasters(Routledge 2018)

105 Valencia Ospina, Prelim Rep. (n.14) para. 39 and Third Report A/CN.4/629 para.88, 'Eighth Report on the Protection of Persons in the Event of Disasters', UN Doc A/CN.4/697 para.290.

${ }^{106}$ IFRC World Disaster Report 2000 (n.8) 153, S. Ali, T. Kabau 'Self-Governance by Humanitarian Non-state Actors in Health and Nutrition Relief’ (2014) 16 DePaul J. Health Care L.141, 148, Cubie (n.31) 66-69.
} 
(iii)Red Cross Code of Conduct for the International Red Cross and Red Crescent Movement and Non-Governmental Organisations in Disaster Relief

The final case study example of autonomous NGO IDL law-making analysed is the Code of Conduct for the International RCRC Movement and Non-Governmental Organisations in Disaster Relief. ${ }^{107}$ Similar to the later Sphere Handbook, it is a voluntary code, 'enforced by the will of the organisation accepting it'. ${ }^{108}$ Although only open to signature by NGOs, this belies both its influence ${ }^{109}$ and its audience. Unlike Sphere, the Code is not an exclusively selfregulatory instrument for NGOs, containing as it does in its Annexes, a number of requests directed at disaster-affected governments, donor states and IGOs, regarding the desired working environment for entities to provide in order to facilitate and optimise humanitarian NGOs' disaster responses. ${ }^{110}$ The ILC continually referenced the Code in the Secretariat Memorandum on the Protection of Persons in the Event of Disasters, ${ }^{111}$ and indeed it is explicitly referenced in the Commentaries to draft Article 3.

Having analysed a selection of NGOs' independent contributions to IDL, the analysis now turns to institutional contributions.

\subsection{Institutional Law-Making: IDL and NGO Participation}

\section{(i)Inter-Agency Standing Committee}

The IASC is a forum which brings together key $\mathrm{UN}$ and non-UN humanitarian partners to facilitate inter-agency coordination of humanitarian assistance ${ }^{112}$ and acts as the central policymaking body of the humanitarian community ${ }^{113}$ 'Standing invitees' of the IASC include the ICRC, IFRC and three NGO consortia: the Steering Committee for Humanitarian Response, Interaction, and the International Council of Voluntary Agencies (ICVA). ${ }^{114}$ The Operational

\footnotetext{
${ }^{107}$ https://www.icrc.org/en/doc/assets/files/publications/icrc-002-1067.pdf

Resolution 4: Principles and action in international humanitarian assistance and protection http://www.ifrc.org/docs/idrl/I413EN.pdf accessed 23 May 2019

${ }^{108}$ Code (n.25) p.1

${ }^{109}$ Sivakumaran, (n.86) 1103-1104.

${ }^{110}$ Including respecting NGOs' impartiality, providing rapid access to disaster victims, facilitating the timely flow of relief goods and information, providing a coordinated disaster information and planning service and providing coordinated disaster information and planning services.

${ }^{111}$ Secretariat Memorandum (n.4) pp.11, 73, 75, 78, 83, 110, 122, 129, 133.

${ }^{112} \mathrm{https}$ ://interagencystandingcommittee.org/ accessed 23 May 2019

${ }^{113}$ IFRC, World Disaster Report 2015 - Focus on local actors, the key to humanitarian effectiveness http://ifrcmedia.org/interactive/wp-content/uploads/2015/09/1293600-World-Disasters-Report-2015_en.pdf at 71 accessed 23 May 2019

${ }^{114}$ Ibid.
} 
Guidelines on the Protection of Persons in Situations of Natural Disaster ${ }^{115}$ were produced by the Office of the Representative of the UN Secretary-General on the human rights of internally displaced persons, after consultation with IASC Working Group members. The IASC Working Group is composed of the directors of policy or equivalent of the IASC member organisations. ${ }^{116}$ While no record of drafting processes is available to the public, NGO participation suggests contributions to the Guidelines' drafting and final approval. There has, however, been criticism of non-inclusive processes which echo Mertus' aforementioned concerns. A 2014 external review of IASC concluded that it is 'generally seen as a "Western Club" and that Southern NGOs were insufficiently represented within the NGO consortia. ${ }^{117}$ Of the IASC's standing invitees, only the IFRC and ICVA include local NGOs directly among their membership, while the other two NGO consortia have members that are networks of local NGOs. ${ }^{118}$ Thus, the policy-making body established to bridge the gap between UN and nonUN organisations (including NGOs) seems to provide uneven access for North/South and global/local NGOs, bearing out common suspicions about meaningful NGO participation.

\section{(ii) The World Conferences on Disaster Risk Reduction: Yokohama, Hyogo, and Sendai}

In 1994, the United Nations Office for Disaster Risk Reduction (UNISDR) held its first UN World Conference on Disaster Risk Reduction which produced the Yokohama Strategy and Plan of Action for a Safer World. This pioneering initiative was followed by outcome documents of the later World Conferences at Hyogo ${ }^{119}$ and Sendai. ${ }^{120}$ NGOs attended all conferences, with accredited NGOs rising from 36 at Yokohama to 188 at Sendai ${ }^{121}$ with some NGO representatives sitting as panellists, and others organising side events. Again, this encourages assumptions of NGO input and influence on final texts which themselves exert considerable influence (the Sendai Framework is extensively referenced in ILC Commentaries). ${ }^{122}$ The Global Network of Civil Society Organisations for Disaster Risk

\footnotetext{
115 http://www.ohchr.org/Documents/Issues/IDPersons/OperationalGuidelines_IDP.pdf (revised version) accessed 23 May 2019.

${ }^{116}$ https://interagencystandingcommittee.org/working-group accessed 23 May 2019.

${ }^{117}$ Sara Pantuliano et al., Review of the IASC: Requested by the IASC Principals Steering Group. (IASC 2014) in World Disaster Report 2015 (n.114) 71.

${ }^{118}$ Ibid.

${ }^{119}$ Hyogo Framework for Action 2005-2015 https://www.unisdr.org/we/inform/publications/1037 accessed 23 May 2019.

${ }^{120}$ Sendai Framework for Disaster Risk Reduction 2015-2030

https://www.unisdr.org/we/inform/publications/43291 accessed 23 May 2019.

${ }^{121} \mathrm{https}$ ://www.unisdr.org/files/45069 proceedingsthirdunitednationsworldc.pdf accessed 23 May 2019

122 See the Commentaries to draft Articles 2 (para.3), 6 (para.9), 7 (paras. 3 and 8), 9 (paras.2, 3, 6, 10, 15, 16 and 18).
} 
Reduction (which has been active at local level since $2009^{123}$ ) submitted a report entitled 'Reality Check - Impact at the Frontline'. ${ }^{124}$ Paragraph 19(f) of the outcome Sendai Framework reads, '...it is necessary to empower local authorities and local communities to reduce disaster risk, including through resources, incentives and decision-making responsibilities, as appropriate'. This is considered a strong stance on local actors' roles in disaster reduction via enhanced collaboration among local-level people to disseminate information via community-based organisations and NGOs. This successful inclusion was attributed to the 'Reality Check' report combined with advocacy from other civil society actors. This implies considerable NGO institutional influence and power ${ }^{125}$ and increasing receptiveness towards NGOs (a development from the 'tepid' treatment of local actors in the Yokohama Strategy). ${ }^{126}$ However, assessments of a positive trajectory are not universal. Some commentators highlight that the Yokohama Strategy recognised the local actors' in determining appropriate international action participation as being of the 'utmost importance', ${ }^{127}$ while the Hyogo Framework referenced the importance of local knowledge (albeit framing it as a tool for the development of top-down advisories). ${ }^{128}$ Sendai instead refers to the importance of 'complementing' scientific knowledge with local knowledge, clearly signalling the secondary role of local actors. ${ }^{129}$ Thus, Sendai is arguably a retrograde step and shifts from valuing community input and local action towards passivity, with understandings of such actors as 'aid recipients'. ${ }^{130}$

It can thus only be inferred that NGOs might have impacted the World Conference outcome documents (with the notable exception of Sendai's paragraph 19(f)). The absence of transcripts or official records of NGO contributions makes impact difficult to quantify. The treatment of NGOs and local actors in the outcome documents is also ambiguous and further doubts equating NGO participation and impact. Moreover, the majority of the NGOs attending Sendai

\footnotetext{
${ }^{123}$ 'Views from the Frontline' - http://www.gndr.org/programmes/vfl.html accessed 23 May 2019.

${ }^{124}$ GNDR, 'How can we ensure impact at the frontline? An implementation plan for civil society, to ensure the post-2015 DRR Framework has an impact at the local level' (March 2015)

http://www.gndr.org/images/newsite/PDFs/Reality \%20Check\%20-\%20Impact $\% 20$ at $\% 20$ the $\% 20$ Frontline_EN. pdf accessed 23 May 2019

${ }^{125}$ Ibid.

${ }^{126}$ World Disaster Report 2015 (n.114) 75-76.

${ }^{127}$ Yokohama Strategy and Plan for Action for a Safer World 1994, https://www.unisdr.org/we/inform/publications/8241 at 5 accessed 23 May 2019

${ }^{128}$ Arielle Tozier de la Poterie, Marie-Ange Baudoin, 'From Yokohama to Sendai - Approaches to Participation in International Disaster Risk Reduction Frameworks', (2015) 6 International. Journal of Disaster Risk Science 128, 133.

${ }^{129}$ Ibid, 135.

${ }^{130}$ Ibid 137.
} 
were, again, well-known international NGOs, rather than small locally active organisations. ${ }^{131}$ Given that the Sendai Framework significantly contoured ILC draft Article 9 on disaster risk reduction and that similar concerns have been expressed regarding that draft Article's tendency towards the passivity of local communities and actors, ${ }^{132}$ it seems that large, international NGO involvement was appropriated and has legitimated an institutional process which may in fact have produced little for local communities.

The next section focuses on NGOs and institutional law-making in the specific context of the ILC Draft Articles.

\section{THE ILC DRAFT ARTICLES AND NON-GOVERNMENTAL ORGANISATIONS:} A STRAIGHTFORWARD RELATIONSHIP?

\subsection{The ILC Draft Articles on the Protection of Persons in the Event of Disasters and NGOs}

NGOS were influential on the draft Articles in several ways. NGOs contributed to the draft Articles' textual development, they lobbied for explicit recognition and as noted, previous NGO-drafted instruments provided prototypes for the ILC instrument. First, as regards the Articles' terms, following their first reading adoption in 2014, the ILC transmitted them to Governments, relevant international organisations and components of the RCRC Movement for comments and observations (which were duly given with some effect). ${ }^{133}$ Secondly, as noted, the Draft Articles and their commentaries explicitly and implicitly reference the central role of non-state 'assisting actors' (as defined in draft Article 3(d) ${ }^{134}$ ) in providing assistance to disaster-affected states. ${ }^{135}$ Finally, as noted already, a number of the key NGO-developed instruments were relied upon by the Special Rapporteur in the drafting process. Most notable among these were the 2007 IFRC/IDRL Guidelines which, as already asserted, provided the substantive and textual template for the Draft Articles.

\footnotetext{
${ }^{131}$ For a list of participants, see 'Proceedings' (n 121).

132 Thérèse O'Donnell 'Vulnerability and The International Law Commission's Draft Articles on the Protection of Persons in the Event of Disasters' (forthcoming in International Comparative Law Quarterly July 2019).

${ }^{133}$ See e.g. Valencia Ospina, Eighth Report (n.105) paras. 86-94.

See in particular R. Connolly, E. Flaux and A. Wu, "Working Paper on the ILC Draft Articles on the Protection of Persons in the event of Disasters", Human Rights Centre, Queen's University Belfast, February 2016 which was specifically cited by the Special Rapporteur, Eighth Report (n.105) para.6.

134 The draft Articles define a non-state assisting actor as 'a competent intergovernmental organization, or a relevant non-governmental organization or entity, providing assistance to an affected State with its consent.

${ }^{135}$ See cross-references to draft Article 7 Commentary, para. 1.
} 
The ILC draft Articles invoke the phrase 'international community' to describe third states, intergovernmental organisations (IGOs), and NGOs which are empowered to offer humanitarian assistance. ${ }^{136}$ Draft Article 12's commentaries note the pre-eminent position of NGOs in the field of disaster assistance ${ }^{137}$ and reflect the common position that, provided certain conditions are fulfilled, such offers are not unfriendly acts or interferences. ${ }^{138}$ The ILC Special Rapporteur considered non-state actors part of 'the acquis of the international law of disaster response ${ }^{\prime 139}$ and described the particular role of humanitarian organisations as 'pivotal' in disaster response. ${ }^{140}$ While there are always concerns regarding the authenticity of their motives, ${ }^{141}$ accountability ${ }^{142}$ and dangers regarding 'open door' policies, ${ }^{143}$ NGOs' central position in the disaster context seems assured by the draft Articles. This reflects various hard international law provisions like the 1998 Tampere Convention ${ }^{144}$ and IHL provisions ${ }^{145}$ in particular, and softer instruments such as the 2004 UNOCHA Guiding Principles on Internal Displacement. $^{146}$ Indeed the commentary to draft Article 7 (which deals with the duty of cooperation) notes that:

The importance of [the IGO and NGO] role has been recognized for some time. In its resolution 46/182, the General Assembly confirmed that:

"Intergovernmental and non-governmental organizations working impartially and with strictly humanitarian motives should continue to make a significant contribution in supplementing national efforts."147

\footnotetext{
${ }^{136}$ ILC, 'Report of the International Law Commission on the Work of its Sixty-sixth Session' (5 May-6 June and 7 July-8 August 2014), UN Doc A/69/10, 129.

${ }^{137}$ Draft Article 12 Commentary, para.5.

${ }^{138}$ San Remo Guiding Principles on the Right to Humanitarian Assistance, Principle 5.

${ }^{139}$ Eduardo Valencia Ospina, 'Fourth Report on the Protection of Persons in the Event of Disasters', UN Doc A/CN.4/643, para.97.

${ }^{140}$ Ibid para.102. See also Dug Cubie The International Legal Protection of Persons in Humanitarian Crises (Hart 2017) 28

141 Karl Penhaul, Dan Simon and Jill Dougherty 'U.S. missionaries charged with kidnapping in Haiti' http://edition.cnn.com/2010/CRIME/02/04/haiti.arrests/ accessed 23 May 2019. Kate van Doore Earthquake orphans: what Nepal can learn from Haiti, https://theconversation.com/earthquake-orphans-what-nepal-can-learnfrom-haiti-41165 accessed 23 May 2019

${ }^{142}$ See IASC 'Protection and Accountability to Affected Populations in the Humanitarian Programme Cycle' (2016) https://interagencystandingcommittee.org/system/files/edg_aap_protection_guidance_note_2016.pdf accessed 23 May 2019

${ }^{143}$ Katrien Beeckman 'International Response to Non-armed Conflict Disasters: Legal Challenges Encountered in Light of the Current Regulatory Framework', (2006) 25(4) Refugee Survey Quarterly 129, 134-135. Cf. potential safeguards mentioned in 2007 IFRC/IDRL Guidelines, 'Introduction,' at 6.

${ }^{144}$ See earlier detail (n.17).

${ }^{145}$ UNOCHA Guiding Principles on Internal Displacement, Principle 25.

Geneva Convention IV (1949) Arts. 23, 30, 38, 59-63,); Additional Protocol I (1977) Art. 70(2), Additional Protocol II (1977) Art. 18(2). See also Jean-Marie Henckaerts \& Louise Doswald-Beck, Customary International Humanitarian Law Vol. I: Rules (CUP 2005), Rule 55.

146 See in particular Principle 25.

147 See annex, para. 5.
} 
In its resolution 2008/36 of 25 July 2008, the Economic and Social Council recognized:

"... the benefits of engagement of and coordination with relevant humanitarian actors to the effectiveness of humanitarian response, and encourage[d] the United Nations to continue to pursue efforts to strengthen partnerships at the global level with the International Red Cross and Red Crescent Movement, relevant humanitarian non-governmental organizations and other participants of the Inter-Agency Standing Committee."148

In total the draft Articles and Commentaries contain 16 references to NGOs and two references to 'civil society'. The broad reference to such entities, ${ }^{149}$ illustrates the ILC's recognition that most assisting actors should be captured. However, despite some definitional open-endedness, the draft Articles' application is limited to assisting actors which are external to the disasteraffected state. Accordingly, neither the activities of domestic NGOs, nor those of domestic actors which secure external assistance, are covered. ${ }^{150}$ Draft Article 3's commentary also stresses the importance of the affected state's consent to external actors' activities, thereby recognising the sometimes broad range of such activities. ${ }^{151}$

Draft Article 4 addresses matters of human dignity and mandates that 'The inherent dignity of the human person shall be respected and protected in the event of disasters'. The ILC acknowledged that ostensibly this obligation might only apply to states given that 'different legal approaches exist as to non-State entities owing legal obligations, [to protect human dignity] under international law'. However, the ILC clarified that despite its brevity, the obligation extended beyond states to 'assisting actors capable of acquiring legal obligations under international law'. It also clarified that it recognised the different roles played by the diverse array of non-state actors. ${ }^{152}$

A key motivating factor for the ILC project was assisting actors' concerns about obstruction or non-cooperation they faced from disaster-stricken states. This imperative for cooperation drove draft Article 7 which states:

\footnotetext{
148 Para. 7.

149 Partly drawn from the ASEAN Agreement on Disaster Management and Emergency Response, 26 July 2005,Article 1, para. 1.

${ }^{150}$ Draft Article 3 Commentary, para. 21.

${ }^{151}$ Draft Article 3 Commentary, para. 22.

${ }^{152}$ Draft Article 4 Commentary, para. 5.
} 
In the application of the present draft articles, States shall, as appropriate, cooperate among themselves, with the United Nations, with the components of the Red Cross and Red Crescent Movement, and with other assisting actors.

However, the commentaries make clear the varying nature of this obligation depending both on the actor and the context in which assistance is sought. The phrase 'as appropriate' qualifies the draft Article both in terms of respecting existing specific rules establishing cooperative obligations among the relevant actors, and permitting contextual determinations as to when cooperation is/is not 'appropriate'. It also circumscribes the actors with whom cooperation should occur. ${ }^{153}$ Express advertence is made to the UN and in particular the special mandate of the Office for the Coordination of Humanitarian Affairs (OCHA) ${ }^{154}$ and the single focal point of the UN Emergency Relief Coordinator. Draft Article 7's reference to 'other assisting actors' cross-references draft Article 3(d)'s definition. However, the ILC felt it appropriate to single out the components of the RCRC Movement, in recognition of the 'important role' it plays in international cooperation in the very situations covered by the draft Articles. ${ }^{155}$ Apart from this, the ILC intended other assisting actors to be broadly conceived and the commentaries cross-reference Paragraphs 19(b) and (d) of the Sendai Framework, which indicate respectively that disaster risk reduction 'requires that responsibilities be shared by central Governments and relevant national authorities, sectors and stakeholders', and that '[it] ... requires an all-ofsociety engagement and partnership'. ${ }^{156}$

Draft Article 8 outlines specific forms of cooperation many of which seem particularly pertinent in the context of major NGO activity. ${ }^{157}$ However, as its commentaries articulate, these are simply illustrative examples and there is no intention 'to create additional legal obligations for either affected states or other assisting actors to engage in certain activities'. ${ }^{158}$ Nevertheless, their appropriateness as assisters for overwhelmed disaster stricken states is also clearly implicated in draft Article 11 which concerns the duty of affected states to seek external assistance. Draft Article 12 adopts a modest tone in expressing that external actors 'may' offer assistance to disaster-affected states. As the commentaries make clear, NGOs can be well-

\footnotetext{
${ }^{153}$ Draft Article 7 Commentary, para. 6.

154 See A/RES/46/182 (n.17).

${ }^{155}$ Draft Article 7 Commentary, para. 8. This reference also includes the ICRC, see draft Article 18 Commentary, para. 8 .

${ }^{156}$ Draft Article 7 Commentary, para. 8.

157 These include humanitarian assistance, coordination of international relief actions and communications, and making available relief personnel, equipment and goods, and scientific, medical and technical resources.

${ }^{158}$ Draft Article 8 Commentary, para. 5.
} 
placed due to their nature, location and expertise, to provide disaster assistance. ${ }^{159}$ This reflects the milestone General Assembly Resolution 43/131 (1988) which urged states, including affected states, to assist and facilitate such organisations' work. ${ }^{160}$ This central role is reinforced by draft Article 16's terms which obligate disaster-affected states to take appropriate measures 'to ensure the protection of relief personnel and of equipment and goods present' in their territories (or under their jurisdiction or control) for the purpose of providing external assistance'. However, although the ILC instrument suggests a secure position for NGOs in disasters, the drafting debates were more fraught than the final terms suggest, and closer analysis suggests an unwillingness to afford assisting NGOs any greater status than they have enjoyed hitherto.

\subsection{Draft Article 12}

Given NGOs' vital humanitarian role in disasters the following analysis will focus on draft Article 12 and external assistance to affected states. The final version of the draft Article states:

1. In the event of disasters, States, the United Nations, and other potential assisting actors may offer assistance to the affected State.

2. When external assistance is sought by an affected State by means of a request addressed to another State, the United Nations, or other potential assisting actor, the addressee shall expeditiously give due consideration to the request and inform the affected State of its reply. This declares the legitimate interest of the international community, states, and organisations when disaster strikes. ${ }^{161}$ However, the simplicity of the draft Article's terms conceals its complex drafting history and its various versions bear analysis for highlighting the ebb and flow in perceptions regarding NGOs' position in disasters and in general international law. The original version of the draft Article proposed in the Special Rapporteur's Fourth Report in 2011 stated:

In responding to disasters, States, the United Nations, other competent intergovernmental organizations and relevant non-governmental organizations shall have the right to offer assistance to the affected State. ${ }^{162}$

\footnotetext{
${ }^{159}$ Draft Article 12 Commentary, para. 5.

160 'in particular [regarding] the supply of food, medicines and health care, for which access to victims is essential'. See also for example the ASEAN Agreement (n.44) Article 4 and the 2011 South Asian Association for Regional Cooperation Agreement on Rapid Response to Natural Disasters, 26 May 2011, Article 4.

${ }^{161}$ ILC, Report of the International Law Commission on the Work of its Sixty-third session' UN Doc A/66/10 277.

${ }^{162}$ Valencia Ospina, Fourth Report, (n.139) 109.
} 
ILC members expressed general support for the provision as a practical manifestation of solidarity ${ }^{163}$ and for highlighting that offers of assistance are generally unproblematic. However criticisms did materialise. Some ILC members objected to the general reference to legal 'rights', since external offers of assistance from the international community were typically extended as part of international cooperation, rather than as an assertion of rights. ${ }^{164}$ In the particular case of NGOs, some ILC members were exercised regarding the language of 'rights', by virtue its implication that NGOs enjoyed the same rights as states. ${ }^{165}$ Some suggested a general drafting alteration which articulated that 'third actors may offer assistance', (thereby providing an authorisation and not a right). ${ }^{166}$ Still others argued for clearer differentiation between assistance emanating from non-affected states and IGOs, and that provided by NGOs, and that references to NGOs 'working with strictly humanitarian motives' should be included. ${ }^{167}$

Having been discussed by the ILC in plenary, the draft provision was then referred to the Drafting Committee of the UN General Assembly's Sixth Committee where its underlying sentiment of solidarity was again well-received. ${ }^{168}$ The Special Rapporteur re-emphasised that the draft provision simply reflected a right to offer, rather than provide, assistance, in accordance both with the principle of sovereignty and the affected state's option of refusal.$^{169}$ Again, considerable attention was given to questions of whether or not such a provision was actually necessary, whether the language of rights was appropriate and what the relationship was between the 'right to offer' and the duty to cooperate'. ${ }^{170}$ However, more pertinent was the apprehension regarding non-state actors' iteration. In particular, there was no mention of any part of the RCRC Movement which led to particular anxieties as to whether it fell within its terms. ${ }^{171}$ More noticeably, states, the UN, other IGOs and NGOs were all specifically

\footnotetext{
${ }^{163} \mathrm{~A} / 66 / 10$ (n.161) para.279.

164 Ibid para. 281.

165 A/66/10 (n.161) para.280. See also the discussion of this Article (then draft Article 16) in: Giulio Bartolini, Tommaso Natoli and Alice Riccardi, Report of the Expert Meeting on the ILC's Draft Articles on the Protection of Persons in the Event of Disasters (2015) Roma Tre University, International Law and Disasters Working Papers Series No.03

${ }^{166} \mathrm{~A} / 66 / 10$ (n.161) para.280.

167 Ibid.

168 Eduardo Valencia Ospina, Fifth Report on the Protection of Persons in the Event of Disasters, UN Doc A/CN.4/652 para. 44 .

169 Valencia Ospina, Ibid, para. 44. In particular he cites positions expressed by Slovenia, (A/C.6/66/SR.20), para.12; Finland (on behalf of the Nordic countries), (A/C.6/66/SR.21), para.60; Poland, ibid., para.86; Mexico, (A/C.6/66/SR.22), para.20; Czech Republic, (A/C.6/66/SR.23), para.19; Austria, ibid. para.25; Chile, (A/C.6/66/SR.24), para.10; Romania, (A/C.6/66/SR.25), para.19; Egypt, ibid., para.36.

${ }^{170}$ Valencia Ospina, Ibid, para. 44-47.

${ }^{171}$ IFRC, (A/C.6/66/SR.25), para.44.
} 
itemised and grouped within the same sentence. This documentary proximity became significant since it was argued that only subjects of international law were entitled to exercise the right to offer assistance. ${ }^{172}$ The draft Articles' textual form therefore raised questions as to whether all of these entities occupied the same juridical footing and possessed identical rights and capacities. Singapore, the Czech Republic and Pakistan all expressed their opposition to any unanimity of treatment for these different actors. ${ }^{173}$ The wording as it stood arguably gave the impression of conferring rights directly on NGOs, which were not subjects of international law. ${ }^{174}$ Particular concerns about potential empowerment of some actors, notably NGOs, were articulated by Germany which argued for a reformulation which distinguished more clearly between third States and IGOs, on the one hand, and NGOs on the other.

The provision was then redrafted to read as follows,

In responding to disasters, States, the United Nations, and other competent intergovernmental organizations have the right to offer assistance to the affected State. Relevant non-governmental organizations may also offer assistance to the affected State. ${ }^{175}$ As is evident, states, the UN, IGOs and NGOs are all specifically mentioned, with the role of NGOs and their capacity to make offers of assistance explicitly recognised. ${ }^{176}$ However, the first three categories of assisting actors are grouped together in one sentence with 'rights' to offer assistance. By contrast, mention of NGOs are separated into a second sentence and expression changed to reflect that they 'might' offer assistance. ${ }^{177}$ This version's commentary maintained that, while emphasising that states, the UN and IGOs were not only entitled, but encouraged, to make offers of assistance, NGOs had a different nature and legal status, and were therefore not in possession of the same rights, or subject to the same legal obligations as the other actors. ${ }^{178}$ This clearly sought to allay the previously mentioned concerns regarding the endowment of NGOs with rights to which they were not entitled. Austria expressed particular support for this differentiation, and considered that although the second sentence acknowledged NGOs' important disaster role, it should not be understood as bestowing

\footnotetext{
172 Valencia Ospina, Fifth Report (n.168) para. 48, Singapore, (A/C.6/66/SR.21), para.75; Mexico, ibid., (A/C.6/66/SR.22), para.20; Czech Republic, (A/C.6/66/SR.23), para.19; Germany, ibid., para.28; Iran, (A/C.6/66/SR.24), para.52; Pakistan, (A/C.6/66/SR.25), para.7; EU (A/C.6/66/SR.21), para.57.

${ }_{173}$ A/C.6/66/SR.21, para. 75., A/C.6/66/SR.23, para.19, A/C.6/66/SR.25, para. 7, respectively.

${ }^{174}$ A/C.6/66/SR.23, para. 28.

175 UN Doc A/CN.4/L.831

${ }^{176}$ ILC, UN Doc A/69/10 (n.136) 129.

${ }_{177}$ Mr. Simonoff (USA) UN Doc A/C.6/68/SR.23 para. 47.

178 Commentary to the (then) Draft Article 16 para.4, A/69/10 (n.136) p.130.
} 
international legal personality upon them. ${ }^{179}$ The US delegation, however, doubted the differentiation's utility, maintaining that while NGOs clearly had a different nature and legal status to states and IGOs, neither affected their capacities to offer assistance to affected states indeed, they should be encouraged to do so. ${ }^{180}$ Its suggestion that the provision be reworded to read that states, the UN, IGOs, and NGOs, could offer assistance without any categorical distinction ended up being closer in spirit to the final version. ${ }^{181}$

Non-state actors also made interventions as to this interim version. In particular, the IFRC was concerned that both it and its member national societies were (still) not mentioned. While it accepted that it was technically appropriate for their non-inclusion in the draft article's iteration (since the RCRC Movement make offers of support to national societies of affected states, not governments) nevertheless, its wording could lead to confusion as to the Movement's right to act in disasters and it urged that the draft Article's commentary should clarify that point. ${ }^{182}$ Similarly, reference to non-governmental humanitarian agencies only being able to offer their services 'changes — and in a way denies — the right of initiative, to which impartial humanitarian organizations such as ICRC are entitled under international humanitarian law and which places such organizations in a privileged position'. ${ }^{183}$ Some NGOs did have rights and this should not be obscured. This point again highlights the considerable heterogeneity of NGOs which goes unrecognised by current definitional shortcomings which group together powerful global actors like the RCRC Movement and grassroots, local NGOs.

In response, the Special Rapporteur indicated that the differentiation of 'right/may' sought to stress the different footings of states and IGOs on one hand, and NGOs on the other. However, he acknowledged that such distinctions were false since all actors could assist, regardless of the legal grounds on which they base their action. Any misunderstandings could therefore be alleviated by employing the term 'other assisting actor' ${ }^{184}$ in place of more specific iterations. ${ }^{185}$ The provision was thus redrafted to read:

\footnotetext{
${ }^{179}$ A/C.6/68/SR.23, para.62 and Valencia Ospina Eighth Report (n.105) paras.306 and 308.

${ }^{180}$ A/C.6/68/SR.23, para.47.

181 'may offer assistance to the affected State, in accordance with international law and applicable domestic laws'.

182 See Ms. Cooper, (IFRC) A/C.6/66/SR.25. The EU also wished clarification that such entities were covered either by express reference in the draft article or within the commentary, UN Doc A/C.6/66/SR.21.

${ }^{183}$ Valencia Ospina, Eighth Report (n.105) para.312.

184 Ibid, para. 315.

${ }^{185}$ ILC, A/69/10 (n.136) draft Article 4(c), at 95 (stating that, “'[O]ther assisting actor' means a competent intergovernmental organization, or a relevant non-governmental organization or any other entity or individual external to the affected State, providing assistance to that State at its request or with its consent.").
} 
In responding to disasters, States, the United Nations and other potential assisting actors may address an offer of assistance to the affected State. ${ }^{186}$

In the ILC's May 2016 meetings, concerns endured about the placing of different actors on the same footing ${ }^{187}$ and indeed one ILC delegate felt uncomfortable with the revised draft of an article which 'had been the result of a hard-won compromise' and which 'now had no prescriptive meaning'. ${ }^{188}$ These latter concerns were partly addressed by the addition of a new second paragraph. This outlined the duty of external actors who received requests for assistance to expeditiously consider and decide upon them, and introduced a 'limited duty of the actor who might possibly be required to give assistance'. ${ }^{189}$ According to the Special Rapporteur, this wording sought to differentiate between the duty of affected states to seek external assistance and the actual making of requests for assistance, which was not a duty. ${ }^{190}$ This amendment, along with some textual simplification ${ }^{191}$ essentially produced the final draft Article as outlined at the opening of this section.

In summary, the current standing of the draft Articles, as a collective instrument, is as a set of non-binding guidelines. It was hoped that this (potentially interim) status would allow for prompt and wide adoption by relevant actors. ${ }^{192}$ Nevertheless, if able to demonstrate evidence of opinio juris and sufficient state practice, the draft Articles could acquire binding customary law status. Indeed, international tribunals have previously relied upon other ILC Draft Articles ${ }^{193}$ even before their finalisation. Such developments would confirm the draft Articles as the most authoritative IDL instrument. Given the apprehensions evident in the debates, somewhat ironically, this status would effectively be achieved while completely bypassing requirements of state consent. This development, together with the importance of the RCRC Movement in the drafting process, and specific NGO recognition in the final text, potentially signals a move away from the traditional state-centred approach towards an increasing NGO

\footnotetext{
${ }^{186}$ Valencia Ospina, Eighth Report (n.105) p.104

${ }^{187}$ Mr. Kolodkin UN Doc A/CN.4/SR.3294.

${ }^{188}$ Ms. Escobar Hernández, UN Doc A/CN.4/SR.3295. See also Messrs. Laraba and Candioti in the same meeting. ${ }^{189}$ UN Doc A/CN.4/SR.3296, p.6

${ }^{190}$ Ibid

191 'may offer assistance' replaced 'may address an offer of assistance' per Mr. Murphy's suggestion A/CN.4/SR.3292.

${ }^{192}$ Ibid, paras 412-413, Valencia Ospina, Prelim. Report (n.14) para 60, Valencia Ospina, Fourth Rep. (n.139), para 25, citing UK and Russian views (A/C.6/65SR.24 \& A/C.6/65SR.23 respectively).

${ }_{193}$ ICJ, Gabčikovo-Nagymaros Project, (Hungary v Slovakia) (Merits) [1997] ICJ Rep 7, Rainbow Warrior (New Zealand v. France) (1990) 82 I.L.R. 500
} 
role in international law-creation. Such a conclusion is bolstered given the Special Rapporteur's aforementioned reliance on pre-existing NGO-developed instruments. However, the fact remains that only particular global entities were engaged in the consultation and much reliance was placed on existing instruments which had already seen less traditional or powerful NGOs 'eased out'. This trickled through to palpable unfamiliarity among even large NGOs during the draft Articles' development ${ }^{194}$ despite nine years of development. Indeed the initiative taken by the Queens University Belfast Human Rights Centre ${ }^{195}$ seems to have been principally due to a particularly vigilant awareness of ILC developments and processes.

The ILC debates highlighted clear concerns and considerable angst about the standing of humanitarian NGOs in international law, and this is the focus of analysis in the next section.

\section{CONCLUSIONS}

\subsection{The Bottom-up Development of International Disaster Law: Closing the Democratic} Deficit?

IDL's bottom-up trajectory ${ }^{196}$ reveals NGOs assuming responsibilities traditionally attributed to states. Indeed state and IGO regulation followed where NGOs had led. As frontline actors, and with governments preferring to funnel aid through international NGOs, ${ }^{197}$ it is perhaps unsurprising that NGOs have a stake in drafting such instruments. Generally, however, the focus of the NGO autonomously-drafted legal instruments is self-regulation rather than managing states' behaviour. Such parallel governance sees NGOs mimicking functions traditionally attributed to nation states. ${ }^{198}$ NGOs' disaster responses (both practical and legal) place them in a potentially powerful position. States' and IGOs' reliance on, and guidance by, NGO expertise and ground experience is palpable throughout the ILC process and documentation. What might be the likely next step for IDL/IDRL? Given the considerable status of the IFRC/IDRL Guidelines and their national integration (which have certainly produced more state practice than the draft Articles) it is unclear if states will eventually rely

\footnotetext{
${ }^{194}$ UCC School of Law - Irish Red Cross Dublin Workshop May 2017

195 See detail at fn. 133 .

${ }^{196}$ Myanna F. Dellinger, 'An Unstoppable Tide - Creating Environmental and Human Rights Law from the Bottom Up', (2013) 15 Oregon Review of International Law 63, 84.

${ }^{197}$ Alejandra de Urioste, 'When Will Help Be on the Way - The Status of International Disaster Response Law' (2006) 15 Tul. J. Int'l \& Comp.L., 181, 199. Some countries allocate more than half Disaster Response budget to NGOs.

${ }^{198}$ PCIJ Case of the S.S. 'Lotus' (1927) PCIJ Rep Series A No 10, 18.
} 
on the ILC instrument, or whether the Guidelines will endure as the most significant reference point. If the latter, then the NGO influence on IDL/IDRL will be indisputably dominant. If, however, the draft Articles move to the forefront, and particularly if a treaty develops, states' reclamation of some IDL territory they feared lost to NGOs might be witnessed.

These conclusions on non-state-centred law-making would be interesting but less important if they represented an isolated example. However, complex problems wrought by climate change and the protection of human rights have also produced significant calls for a reversal of traditional law-making approaches. ${ }^{199}$ Boutros Boutros-Ghali once admitted that sovereignty, not democracy, was the international legal system's guiding principle. ${ }^{200}$ However, he concluded that 'a fundamental conceptual transformation ....[of]... democratization' 201 was potentially underway. ${ }^{202}$ This has two aspects. The first point concerns whether NGO participation renders more democratic international law-making. NGO inclusion might hearten those critics who lament international law's democratic deficit, ${ }^{203}$ but who nevertheless see a more widely participatory system of formalism as potentially retaining value. ${ }^{204}$ However, such perceptions are tested by realities. ${ }^{205}$ Although NGO-attendance at international IDL lawmaking fora is normalised, concrete influence is difficult to quantify. ${ }^{206}$ Further, where NGOs impact law's development, their participation creates a 'paradox' wherein NGOs are active '.... in the functioning of international institutions and the implementation of the law created in their midst' even though de jure, they have little (or only a narrowly defined) existence. ${ }^{207}$

\footnotetext{
${ }^{199}$ See for example, Stephan Hobe 'Global Challenges to Statehood - The Increasingly Important Role of Nongovernmental Organisations’ (1997) 5 Indiana .Journal of Global Legal Studies, 191; Dellinger (n.179); Kerstin Martens, 'Examining the (Non-Status) of NGOs in International Law' (2003) 10(2) Indiana Journal of Global Legal Studies 1.

${ }^{200}$ Boutros Boutros-Ghali, 'Democracy - A Newly Recognized Imperative' (1995) 1 Global Governance 3, 9 , Steven Wheatley, The Democratic Legitimacy of International Law (Hart 2010) 12 ${ }^{201}$ Ibid.

202 Thomas M. Franck, 'The Emerging Right to Democratic Governance' (1992) 86(1) American Journal of International Law 46, Richard Burchill, 'The Developing International Law of Democracy', (2001) 64 Modern Law Review 123.

203 Burchill, ibid, 22.

${ }^{204}$ Martti Koskenniemi, 'The Lady Doth Protest Too Much - Kosovo, and the Turn to Ethics in International Law' (2002) 65(2) Modern Law Review 159, 174-175.

${ }^{205}$ Martens (n.199) 3.

${ }^{206}$ See similar analysis regarding the World Summit on the Information Society, Charlotte Dany 'Janus-Faced NGO Participation in Global Governance - Structural Constraints on NGO Influence', (2014) 20 Global Governance, 419, 423. For experience in the environmental field, Peter J.Spiro, 'NGOs in International Environmental Lawmaking-Theoretical Models', in Daniel Bodansky, Jutta Brunée and Ellen Hey (eds.) Oxford Handbook of International Environmental Law (OUP 2007).

${ }^{207}$ Pierre-Marie Dupuy, 'Conclusion' 202, 214 in Pierre-Marie Dupuy \& Luisa Vierruci (eds.) NGOs in International Law - Efficiency in Flexibility?, (Elgar 2008), Steve Charnovitz, 'The Illegitimacy of Preventing NGO Participation’ (2011) 36 Brooklyn Journal of International Law, 891, 892
} 
While in the immediate term, NGO presence lends considerable legitimacy to outcome documents, debilitating suspicions about tokenism and transparency shortfalls can equally degrade their currency.

The second aspect to NGOs' democratising potential ${ }^{208}$ concerns their representative mandate. Characterised as honest humanitarian brokers, they often enjoy perceptions of inherent legitimacy as representatives of global civil society and the 'muffled masses'. ${ }^{209}$ However, power imbalances between NGOs, domination of NGO offices by wealthier, better-educated elites $^{210}$ and the replication of state power structures cast doubt on their democratising potential and abilities to represent marginalised and struggling disaster-stricken communities. ${ }^{211}$ NGOs can advance their agendas by instrumentalising the international system, without being answerable to it. ${ }^{212}$ This both facilitates potentially harmful tunnel vision (which may fail to countenance political, economic or social contexts and consequences ${ }^{213}$ ) and diminishes perceptions of NGOs' legitimacy. It is conceded that this may not corrupt final instruments given that their validity traditionally remains unquestioned even if some of the participating states are not democratically structured. ${ }^{214}$ However, again, the least desirable aspects of Westphalian law-making remain and may even be reinforced by NGO participation.

\subsection{The Way Forward?}

Increasing NGO participation and recognition in international law brings opportunities and challenges and it must be tackled in the international society we occupy, 'not from some wishful construction of it. ${ }^{, 215}$ As noted, one option is to recognise an enhanced form of legal personality for NGOs which, surprisingly, may restrain rather than escalate their power. ${ }^{216}$ For example, while enhanced legal capacities would entail participation rights (and perhaps remove notions of NGOs as state-handmaidens) ${ }^{217}$ it would also oblige NGOs to respect negotiated

\footnotetext{
${ }^{208}$ Menno T.Kamminga, 'The Evolving Status of NGOs Under International Law - A Threat to the Inter-State System?' in Gerard Kreijen, Marcel Brus, Jorris Duursma, Elizabeth De Vos, and John Dugard (eds), State, Sovereignty, and International Governance (OUP 2002)

${ }^{209}$ Rana Lehr-Lehnardt, 'NGO Legitimacy - Reassessing Democracy, Accountability and Transparency' (2005) Cornell Law School Inter-University Graduate Student Conference Papers. Paper 6. https://scholarship.law.cornell.edu/lps_clacp/6/ at 2 accessed 23 May 2019.

${ }^{210}$ Ibid 23.

${ }^{211}$ Secretariat Memorandum (n.4) 1.

212 Peter J.Spiro, 'Accounting for NGOs' (2002) 3 Chicago Journal of International Law, 161, 166.

${ }^{213}$ Lehr-Lehnardt (n.209) 27.

${ }^{214}$ Wolfrum (n.30) 83.

${ }^{215}$ Koskenniemi (n.29) 573.

${ }^{216}$ P.Spiro (n.212)167.

${ }^{217}$ Dany (n.206) 422.
} 
results and remove their informal, external power. This might entail letting-go of some 'outside' tools such as campaigns ${ }^{218}$ Further, although enhanced personality might recognise the reality that NGOs effectively already have a 'seat at the table', ${ }^{219}$ it would likely extend only to particular organisations. This would therefore replicate previous problematic institutional experiences and actually retrench larger Western NGOs' privileges. Recognition of all ECOSOC-accredited NGOs (currently standing at 5,161) ${ }^{220}$ seems unfeasible, but revising ECOSOC criteria to be less financially burdensome to NGOs with limited resources might enhance equality of access. ${ }^{221}$ Clarification of the currently opaque provisions ${ }^{222}$ for the withdrawal of consultative status might also benefit perceptions of enhanced NGO accountability. Such re-thinking would move the debate on from arid discussions as to whether NGOs possess personality to focus on recognising their legal reality and the appropriate and feasible responses.

The ILC Draft Articles offer an interesting analytical frame for considering the position of NGOs in international law. State discomfort with, but simultaneous reliance upon, NGO field and drafting activity came into sharp focus in the ILC project. Traditional perceptions of NGOs as state-antagonists are clearly misplaced (for both positive and negative reasons) as are assumptions that NGOs perfectly represent global civil society. The success of certain NGOdrafted instruments suggest that NGOs achieve more outside than within institutionalised lawmaking structures. This implies that NGOs have embraced their quasi-legal personality, and by reconfiguring it in particular ways, have actually changed law-making processes in a particular field. A 'golden thread' might be said to weave from the 1994 Red Cross Code of Conduct to the draft Articles. However, although such instruments often have progressive and practically vital qualities, the absence of appropriate regulation, accountability mechanisms and transparency mean these are not necessarily unalloyed goods. Further, the unregulated nature of NGOs' impact on international law stands in direct contrast to positivist legal doctrine. How international law responds to this potential power shift in global governance

\footnotetext{
218 Spiro (n.201) 167.

219 Ibid.

220 UN Department of Economic and Social Affairs, 'Basic Facts about ECOSOC Status' http://csonet.org/?menu=100 accessed 23 May 2019

${ }^{221}$ For example, the present criteria require that regional, subregional and national organisations may only be admitted provided they can demonstrate work programmes are directly relevant to UN aims and purposes, E/RES/1996/31 (n.116) para.8.

${ }^{222}$ Paragraph 57(a) currently reads that consultative status may be withdrawn if an organisation 'abuses its status by engaging in a pattern of acts contrary to the purposes and principles' of the UN Charter, ibid, para.57(a).
} 
remains unknown. In the particular context of the ILC draft Articles, states might choose to reclaim territory in a treaty but this seems unlikely in the short term at least. Thus, the twilight world of the General Assembly's 'recommended' usage of the ILC instrument suggests that states and international lawyers will continue in a loving, but commitment-phobic relationship, both towards the draft Articles and NGOs themselves. 